\title{
The use of artificial spawning substrates in order to understand the factors influencing the spawning site selection, depth of egg strands deposition and hatching time of perch (Perca fluviatilis L.)
}

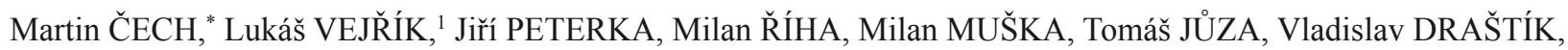 \\ Michal KRATOCHVÍL and Jan KUBEČKA \\ Biology Centre, Academy of Sciences of the Czech Republic, Institute of Hydrobiology, Na Sádkách 7, 37005 České Budějovice, \\ Czech Republic; ${ }^{1}$ Faculty of Science, University of South Bohemia, Branišovská 31, 37005 České Budějovice, Czech Republic \\ *Corresponding author: carcharhinusleucas@yahoo.com
}

\begin{abstract}
The distribution of egg strands of perch Perca fluviatilis and factors affecting this distribution, in terms of spawning sites and spawning depths used, was studied in spring 2010 in Chabařovice Lake, Czech Republic, using areas with an artificial spawning substrate (A.S.S.) and control areas outside the A.S.S. Perch significantly preferred a calm shore instead of a windward shore for spawning. The depths at which perch egg strands were found increased significantly during the spawning period in both A.S.S. areas and in areas outside the A.S.S. (on average from $4.9 \mathrm{~m}$ at the beginning to $12.3 \mathrm{~m}$ at the end of the spawning period). With increasing depth of deposition the size of the egg strands decreased significantly. The mean depth of egg strands on individual dates corresponded to the position of $10-12^{\circ} \mathrm{C}$ water layers. From the third week onward, however, egg strands were deposited in much deeper and colder water. A strong relationship was found between the depth at which egg strands were deposited and the duration of the daylight period, indicating that, at the end of the spawning season, perch do not react to the actual temperature of the water column but that they follow their inner clock, assuming that "normally" the shallower depth layers are too warm for successful embryo development. Factors influencing the depth distribution of egg strands were identified as waves, temperature and duration of the daylight period. Factors influencing the selection of spawning sites were identified as wind inducing current, internal seiches and temperature instability of the water column. The first perch larvae were present in the open water of Chabařvice Lake before mid-May, and the latest larvae not earlier than the beginning of July, since warming of the water in deeper layers was very slow. It appears that with prolonged spawning and hatching periods and with spawning occurring at various depths and temperatures, perch have evolved a powerful mechanism to protect their population against the vagaries of the weather and temporary bad biological conditions in the lake.
\end{abstract}

Key words: Chabařovice Lake, SCUBA diving, aquatic vegetation, common stonewort Chara vulgaris, Eurasian water milfoil Myriophyllum spicatum; lake management.

Received: August 2011. Accepted: November 2011.

\section{INTRODUCTION}

The selection of an appropriate spawning site, substrate and depth is crucial for successful fish reproduction and for overall population recruitment and, more-over, in terms of gene flow it is crucial for the fitness of individual females. This is especially true for fish which deposit all their eggs of the year in one clutch, as do perch, Perca fluviatilis L. in Eurasia and P. flavescens (Mitchill) in North America (Thorpe 1977; Treasurer 1983; Craig 1987). A mistake in the selection of an appropriate site, substrate or depth for spawning may easily result in complete failure of reproduction. Clady, and Hutchinson (1975) showed that, as a result of one day of high winds, large quantities of perch egg strands were washed ashore at a number of locations on the wind-ward shoreline of Oneida Lake. Wind-generated waves force perch to spawn in deeper water than expected (cf. e.g., Holčík 1969; Thorpe 1977; Craig 1987) in
Lake Zürich (Zeh et al. 1989) and in Lake Geneva (Gillet et al. 1995; Gillet, and Dubois 1995; Gillet, and Dubois 2007). Similarly, waves generated by car ferries and passenger cruise ships affect the depth of perch spawning in Lake Constance (Probst et al. 2009). The selection of a calm, instead of a windward, shore was observed for spawning perch by Jones (1982). The wind/wave action could not only damage the egg strands mechanically, but could also induce large internal seiches. This extreme mass movement of water may cause thermal shocking of developing embryos (Aalto, and Newsome 1989) and increase egg mortality or the presence of body abnormalities in hatched fry, leading to greater susceptibility to predation (Newsome, and Aalto 1987).

In general, temperature, and especially high temperature, is a fundamental factor affecting the success of reproduction in perch. Temperatures $>14^{\circ} \mathrm{C}$ increase egg mortality (Guma'a 1978) and even higher temperatures, 
e.g. in areas with heated effluents from nuclear power stations, cause egg strands not to develop to hatching (Sandström et al. 1997).

Williamson et al. (1997) have shown experimentally that a low concentration of dissolved organic carbon (DOC) strongly influences the underwater level of damaging solar ultraviolet radiation (UVR) in freshwaters and that in lowDOC lakes the UVR kills all the egg strands when they are spawned in shallow water. For that reason, perch spawn much deeper in low-DOC lakes compared to higher-DOC lakes in order to protect their eggs against dangerous UVR (Huff et al. 2004).

Although in Chabařovice Lake the depth distribution of perch egg strands displays (according to the classification of Huff et al. 2004) all signs of a low-DOC lake (Čech et al. 2009, 2010, 2011), the concentration of DOC has suggested that the lake actually belongs to the category of higher-DOC lakes, where the damaging effect of UVR on egg strands is negligible. However, in this lake the great majority of egg strands is deposited at depths greater than 3 m each year (Čech et al. 2011), many of them in the deepest depth layers ever published (Čech et al. 2009, 2010). Until now it could only be speculated as to which factors are basically responsible for such deep spawning of perch in this lake, since not only wind/waves and temperature but also perch substrate selection (dead vegetation with hard three-dimensional structures preferred; Čech et al. 2009) and spawning site selection (sites with wind-transported warm water preferred; Čech et al. 2011) have been shown to play a role in the distribution of egg strands.

To understand the main factor controlling the depth of deposition of perch egg strands in Chabařovice Lake, in 2010 an artificial spawning substrate (A.S.S.) was installed in the lake in an attempt to homogenize spawning sites and spawning depths and, after years of monitoring of "natural" processes, to transform at least part of the study area into more experimental conditions. Another objective of installing the A.S.S. was to improve spawning possibilities for perch in the lake because the most important substrate for perch spawning - beds of dead common reed Phragmites communis and worm weed Artemisia sp. - has shown signs of progressive degradation over the years, and moreover, due to the continuous filling of the lake, most of it has been submerged into very deep water ( ̌ Cech et al. 2009, 2010, 2011).

The main questions of the present study were: (1) Is the perch spawning behaviour concerning preference for individual parts of the lake, individual depth layers etc. similar in areas with A.S.S. and areas outside of the A.S.S.? (2) Is the avoidance reaction of spawning perch to very shallow water (basically 0-1 but also 1-3 m) reported for Chabařovice Lake by Čech et al. $(2009,2010,2011)$ a result of absence of appropriate spawning substrate, or of wind/wave action? (3) Does the size of egg strands really decrease during the season and with increasing depth of deposition as was suggested by preliminary results of Čech et al. (2011)? (4) What are the durations of the spawning, incubation and hatching periods in the conditions of a lake where perch spawning takes place to a depth of over $20 \mathrm{~m}$ ? (5) Is the trend of decreasing numbers of spawned egg strands recorded for Chabařovice Lake between 2007-2009 (Čech et al. 2009, 2010, 2011) a result of progressive degradation of the most important perch spawning substrates or simply a result of decreasing size of perch spawning stock?

The study is part of a long-term project focusing on succession processes in a restored opencast mine lake where aquatic restoration has been applied. Therefore, the perspectives of using A.S.S. to enhance the reproductive success of perch in this type of lake are also evaluated and discussed.

\section{MATERIALS AND METHODS}

Study area

The study was carried out in the oligo- to mesotrophic Chabařovice Lake, Czech Republic (80 km north-west of Prague), which has an area of $c a 250$ ha, volume of $35 \times 10^{6}$ $\mathrm{m}^{3}$ and maximum depth of $25 \mathrm{~m}$ (Fig. 1a).

Chabařovice Lake is a newly created, opencast mine lake where aquatic restoration started in 2001 (Čech et al. 2009). This water body initially had no obvious limitation to perch spawning activity in terms of depth and spawning substrates, which were numerous (e.g., dead trees, dislodged branches, bushes, beds of dead common reed and worm weed, curly pondweed Potamogeton crispus, Eurasian water milfoil Myriophyllum spicatum and common stonewort Chara vulgaris) and at least some of them

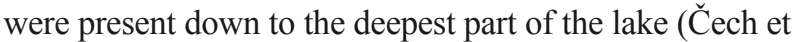
al. 2009, 2010). However, especially beds of dead common reed and worm weed, the most important substrate for perch spawning, have shown signs of progressive degradation over the years. This imposes a potential threat for the population of perch, the most abundant predatory fish in the lake (Čech et al. 2009, 2010, 2011). Moreover, the presence of live submerged vegetation (suboptimal perch spawning substrate) is less predictable in time and depends on the weather conditions during the year and the system of lake filling (Čech et al. 2009, 2011). For example, the large stands of curly pondweed, which were enormously abundant in spring 2007 (resembling well grown kelp forest; Čech et al. 2009) had severely degraded in late fall 2007 ( $<<5 \%$ of the 2007 situation was observed in spring 2008; Čech et al. 2010) and completely vanished from the lake in 2009 (Čech et al. 2011).

\section{Experimental design}

For the above mentioned reason, in mid-April 2010 the A.S.S. was installed at two localities in the lake to (1) max- 


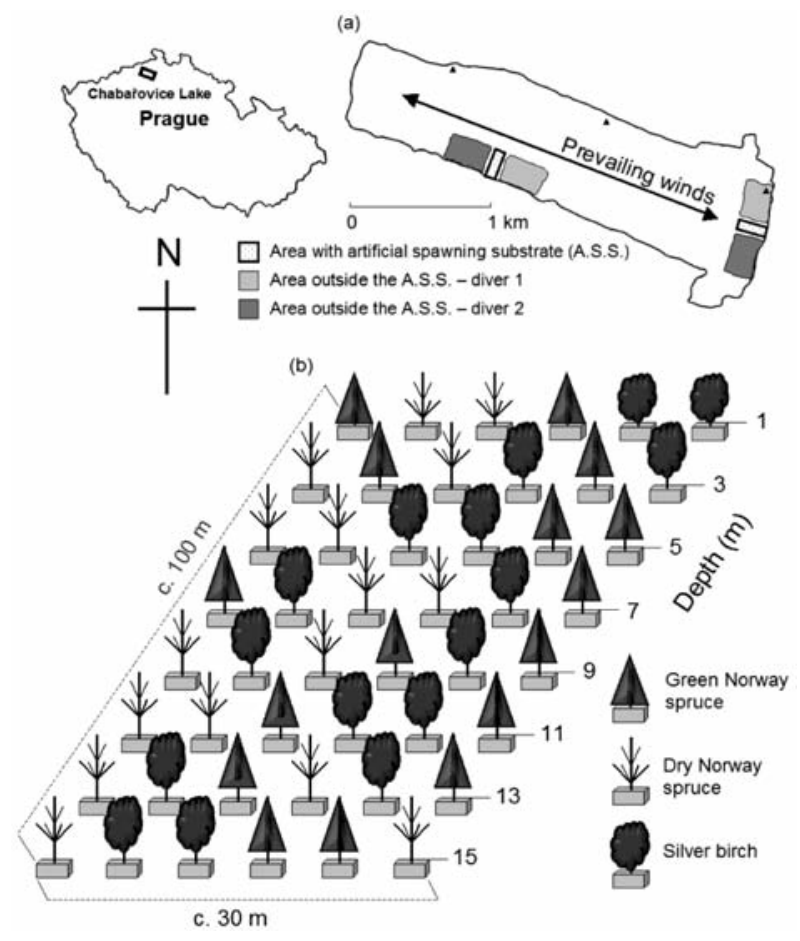

Fig. 1. A map of Chabařovice Lake and its location in the Czech Republic. (a) An outline map of the lake showing locations of areas with artificial spawning substrate (A.S.S.) for perch and neighbouring, control areas outside the A.S.S. in the east and in the south. Areas outside the A.S.S. were monitored using systematic, parallel transect sampling from $0 \mathrm{~m}$ towards the $15 \mathrm{~m}$ depth. Temperature and dissolved oxygen were measured at the edge of each A.S.S. area in the whole water column above 3, 7, 11 and $15 \mathrm{~m}$ depths on the sampling day (midday). Black triangles indicate the locations where surface water temperature was measured daily from 15 March (morning). (b) A schematic view of an A.S.S. area with the actual positions of each individual tree type - 16 green Norway spruce, 16 dry Norway spruce, 16 silver birch.

imize the standardization of the research area in terms of spawning substrate (the presence of completely the same spawning substrate at various depths and in various localities, in order to better identify other factors influencing the location and depth of perch spawning activity) and to (2) improve the spawning possibilities for the perch. Altogether, 96 trees (32 green Norway spruce Picea abies, 32 dry Norway spruce, 32 silver birch Betula pendula) $2 \mathrm{~m}$ high were installed on the east (windward area) and south (calm area) shores of the lake to depths of 1, 3, 5, 7, 9, 11, 13 and $15 \mathrm{~m}$, i.e. the whole slope from 0 to $15 \mathrm{~m}$ depth was completely covered with A.S.S.; no depth layer was omitted. Trees installed in water $1 \mathrm{~m}$ deep were cut to be only 1 $\mathrm{m}$ high and not to emerge from the water. At each of the two localities, 48 trees were installed, 2 green Norway spruce, 2 dry Norway spruce and 2 silver birch at each individual depth (Fig. 1b). The position of each individual tree type was chosen randomly for each depth, but the se- quence of tree types was the same in both the east and south A.S.S. areas, i.e. the A.S.S. areas were identical.

Each tree was fixed with screws and concrete into a 24 $\mathrm{kg}$ concrete paving slab serving as a weight and anchor. The trees were installed from the boat, the depth of installation was determined using a commercial echosounder Eagle Ultra Classic. A SCUBA diver then checked the depth and position of each individual tree. When necessary, the tree was reinstalled underwater. All six trees in each line were connected together with a rope $3 \mathrm{~mm}$ in diameter (the connecting rope followed the depth contour; the distance between individual trees in the line was ca $5 \mathrm{~m}$ ); the first tree in the line was connected to an anchored buoy in order to be easily found both underwater and from the water surface. The distance between individual lines was $14 \pm 6 \mathrm{~m}$ (mean \pm S.D.). Each tree was individually labelled to ensure its unique, unmistakable position in the A.S.S. area and in subsequent divers' records.

\section{Sampling}

Two SCUBA divers monitored perch spawning activity in the A.S.S areas for five weeks between 3 May and 3 June 2010 (1-3 times a week). For comparison, additional dives were made in neighbouring, control areas outside the A.S.S., once a week (see Fig. 1a). In the A.S.S. areas, the diver checked each individual tree, counted and measured (width; using a ruler) all new egg strands and wrote down the depth of deposition. For older egg strands (already counted and measured), the diver recorded their actual developmental stage according to the classification of Guma'a (1978). This information was noted underwater on a special plastic tablet (one tablet for each diver and locality) with the stated position of each individual tree in the A.S.S. area and all the historical records of older egg strands deposited on this particular tree. Old egg strands were not removed from the A.S.S. as was done in the work of e.g. Gillet, and Dubois (2007) or Probst et al. (2009), in an effort to evaluate possible/expected competition for spawning substrates.

In areas outside the A.S.S., the divers monitored perch spawning activity in 0-15 m depth layers using systematic parallel transect sampling (Čech et al. 2011). The diver swam from a very shallow littoral zone (depth $0 \mathrm{~m}$ ) towards the depth of $15 \mathrm{~m}$ (transect 1), sampling the space of $3 \mathrm{~m}$ to each side of him, then turned $90^{\circ}$, performed ten standard fin strokes ( $c$ a $15 \mathrm{~m}$ distance - not sampled), turned another $90^{\circ}$ and swam back from $15 \mathrm{~m}$ towards the $0 \mathrm{~m}$ depth (transect 2 ). The diver recorded the type of substrate on which individual egg strands were deposited, the depth of their deposition, the size of the egg strands and their developmental stage according to the classification of Guma'a (1978). This information was noted underwater on a plastic slate for each individual egg strand in each individual transect.

Temperature and dissolved oxygen in the whole water 
column were measured at midday using a calibrated YSI 556 MPS probe on the dates when the A.S.S. areas were sampled (above 3, 7, 11 and $15 \mathrm{~m}$ depths on the edge of each A.S.S. area). Surface water temperature was measured daily (morning) from 15 March at three separate locations round the lake shore (Fig. 1a) in order to detect the beginning of the perch spawning period at $8-10^{\circ} \mathrm{C}$ (Kubečka 1992).

During the complex fish stock assessments of Chabařovice Lake in years 2006-2009 (September; hydroacoustics, fry beach seining, fry trawling, SCUBA diving, gillnets) perch were caught by Nordic multi-mesh gillnets, which were exposed overnight (installed at 18:0020:00 hours and lifted the next day at 6:00-8:00 hours). Gillnets were made according to the European standard EN 14757 (CEN, 2005) by the Pokorný - sítě company, Brloh, Czech Republic. Both benthic gillnets (set to the depth layers 0-3, 4-6, 7-8, 11-13 and 17-20 m) and pelagic gillnets (epipelagic, mesopelagic, bathypelagic) were used. Altogether, $26,025 \mathrm{~m}^{2}$ of gillnets were exposed during the years $2006-2009\left(5520 \mathrm{~m}^{2}\right.$ in $2006,6240 \mathrm{~m}^{2}$ in 2007,6300 $\mathrm{m}^{2}$ in 2008 and $7965 \mathrm{~m}^{2}$ in 2009). All perch caught were measured to the nearest $0.5 \mathrm{~cm}$ (Kubečka et al. 2007; Peterka et al. 2008, 2009, 2010). The SCUBA diving results from 2007 and 2009 have shown that in Chabařovice Lake $97 \%$ and $92 \%$ of perch egg strands were spawned by females $\geq 200 \mathrm{~mm} L_{S}$ (Čech et al. 2009; M. Čech, J. Peterka, M. Ríha, unpubl. data). The sizes of the female perch that had contributed to the spawning were reconstructed from the width of individual egg strands using the equation of Dubois et al. (1996). The monitoring of sex ratios in individual size groups of perch in Chabařovice Lake has further revealed that in September 2009 almost 89\% of fish $\geq 200 \mathrm{~mm}_{S}$ were females $\left(\mathrm{n}_{\text {total fish dissected }}=801,108\right.$ fish were $\geq 200$ mm LS; M. Čech, L. Vejř́ik, J. Peterka, unpubl. data). Therefore, only gillnetted perch $\geq 200 \mathrm{~mm} L_{S}$ were considered for the analysis to evaluate whether the trend in decreasing numbers of spawned egg strands is caused by decreasing size of the perch spawning stock. The gillnet results from 2006-2009 were expressed as catch per unit of effort (CPUE; in perch $\geq 200 \mathrm{~mm} L_{S} 1000 \mathrm{~m}^{-2}$ of gillnets) and used in the relationship with CPUE of egg strands found per 10 hours of diving during the SCUBA research in the following springs (years 2007-2010; Čech et al. 2009, 2010, 2011, this study). The final relationship between the size of perch spawning stock and the number of spawned egg strands was created using year $\mathrm{X}$ of the SCUBA data and year X-1 of the gillnet data since this comparison is not biased by the growing season, i.e. female perch of $200 \mathrm{~mm} L_{S}$ caught in year X-1 (September - gillnet sampling) will be of approximately the same size in year X (April/May - spawning season). The authors are aware that this approach is, on the other hand, biased by winter perch mortality.

\section{Statistical analyses}

The data were tested using regression analysis (relationship between the week of spawning and the depth of egg strands deposition; relationship between the duration of the daylight period and the depth of egg strands deposition; relationship between the width of egg strands and the depth of their deposition; relationship between the CPUE of perch $\geq 200 \mathrm{~mm} L_{S}$ caught by gillnets in year X-1 and the CPUE of egg strands found during the SCUBA research in year $\mathrm{X}), \chi^{2}$ - test (preferences for the A.S.S. areas - east $v s$ south; preference for areas outside the A.S.S. - east vs south; preference for individual types of A.S.S. - green Norway spruce vs dry Norway spruce vs silver birch) and one-way ANOVA for unequal $n$ (depth of egg strands according to the type of A.S.S. exploited and according to the chosen locality; width of egg strands according to the type of A.S.S. exploited and according to the chosen locality).

\section{RESULTS}

During the five-week period of sampling in Chabařovice Lake nine dives were made on each A.S.S. area and four dives in each area outside the A.S.S. $(2 \times 10$ transects during each sampling survey in each area outside the A.S.S. covering $\mathrm{ca} 30,000 \mathrm{~m}^{2}$ of the lake bottom; the last week was not sampled due to time limitation). In total, the divers spent almost 43 hours underwater.

The depths of perch egg strands increased significantly during the spawning period in both A.S.S. areas (regression analysis; $\left.F_{1,78}=46.50, p<0.001\right)$ and in areas outside the A.S.S. (regression analysis; $F_{1,42}=45.45, p<0.001$; Fig. 2 ). The mean depth of the egg strands on individual dates corresponds to the position of the $10-12^{\circ} \mathrm{C}$ water layers (mostly representing the thermocline, or at least part of the thermocline).

However, from the third week onwards, the egg strands were deposited in much deeper and colder water (Fig. 3 and cf. Fig. 2). The pooled data from the A.S.S. areas and from areas outside the A.S.S. showed that $76.6 \%$ of egg strands were deposited in the thermocline or under the thermocline (76.3\% in the case of A.S.S. areas and $77.3 \%$ in the case of areas outside the A.S.S.). During the whole sampling period $92.5 \%$ of the egg strands were found at depths greater than $3 \mathrm{~m}$ in A.S.S. areas and $95.5 \%$ in areas outside the A.S.S. No egg strands were spawned onto the A.S.S. installed between 0-1 m deep and in the case of the eastern A.S.S. area the A.S.S. installed between 1-3 metres was also empty. A clear, overall avoidance of the shallowest depth layers was caused by wind and waves (e.g., up to $1 \mathrm{~m}$ high waves accompanied by a strong current were observed close to the east shore of the lake during the third week of sampling) since no egg strands were found shallower than $1 \mathrm{~m}$ also in areas outside the A.S.S. The avoidance of the 1-3 m depth layers in the case of the eastern A.S.S. area was caused by 


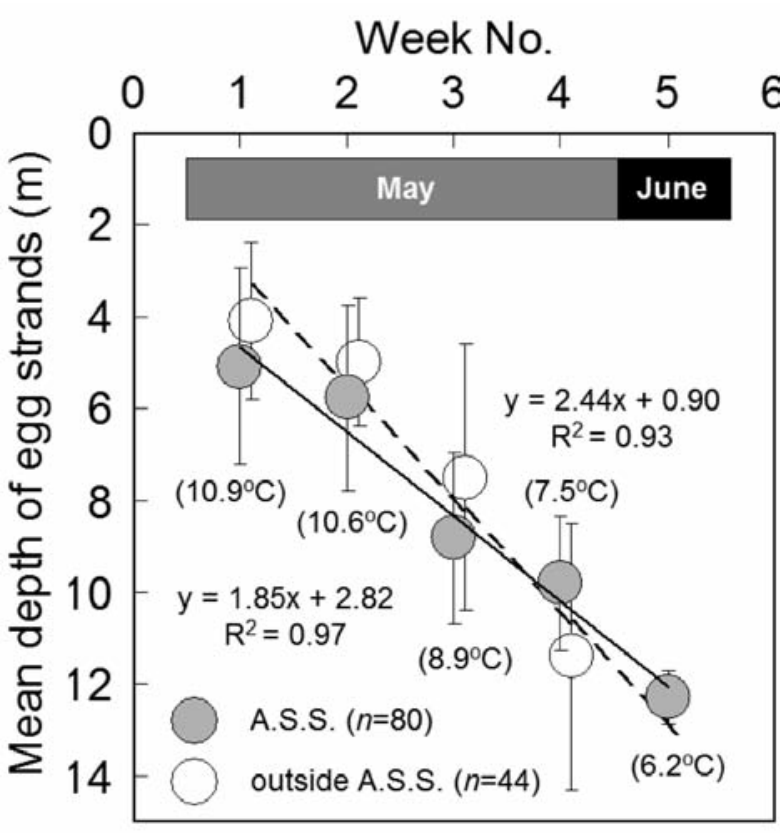

Fig. 2. The relationship between the week of sampling and depth (mean \pm S.D.) of newly spawned egg strands of perch in Chabařovice Lake in the A.S.S. areas and areas outside the A.S.S. (3 May - 3 June 2010). The mean temperature of the egg strands' incubation is given for the A.S.S. areas and individual weeks.

thermal instability of the water column (Fig. 3a), again induced by wind and waves generating extensive internal seiches. This phenomenon was much less apparent in the southern A.S.S. area, which was chosen to be almost on the transverse axis of that water mass movement (cf. Fig. 3b). A strong relationship was found between the depth of deposition of egg strands and the duration of the daylight period (regression analysis; $F_{1,122}=77.86, p<0.001$; Fig. 4).

Perch significantly preferred the southern A.S.S. area for spawning rather than the eastern A.S.S. area $\left(\chi^{2}=5.00\right.$, d.f. $=1, p<0.05)$, since 50 egg strands were found in the former and only 30 in the latter area. The same preference was evident for southern areas outside the A.S.S. $\left(\chi^{2}=13.09\right.$, d.f. $=1, p<0.001)$ since 34 egg strands were found close to the south shore and only 10 close to the east shore. Numerically, perch also preferred to deposit their egg strands on both green and dry Norway spruce and avoided the silver birch, since 32 egg strands were found on green Norway spruce, 31 on dry Norway spruce and only 17 on silver birch. This preference was, however, not statistically significant $\left(\chi^{2}=5.27\right.$, d.f. $\left.=1, \mathrm{p}=0.072\right)$.

The depth of the egg strands did not differ between individual A.S.S. (ANOVA; $\mathrm{F}_{2,77}=0.43, \mathrm{p}=0.65$ ) being, on average, $6.4 \mathrm{~m}$ on green Norway spruce, $6.1 \mathrm{~m}$ on dry Norway spruce and $5.7 \mathrm{~m}$ on silver birch (no new egg strands were found on the last tree type from 18 May onward). Similarly, the depth of egg strands did not differ between the eastern and southern localities (ANOVA; $F_{1,122}=0.02$,
Date
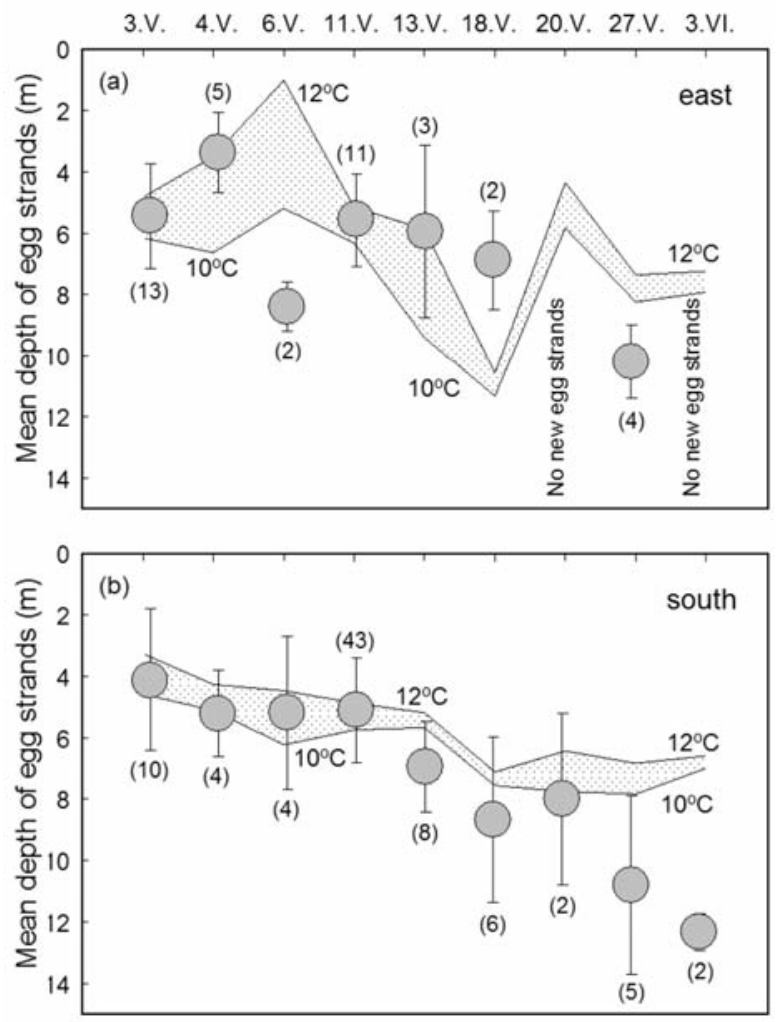

Fig. 3. Depths (mean \pm S.D.) of newly spawned egg strands of perch on individual dates (combined data from the A.S.S. areas and areas outside the A.S.S.) and the position of the 12 and $10^{\circ} \mathrm{C}$ water layers in the east (a) and south (b) part of Chabařovice Lake (spring 2010). Numbers in parentheses indicate numbers of newly spawned egg strands. Note the extensive movement of the 12 and $10^{\circ} \mathrm{C}$ water layers (internal seiches) in the east in contrast to the south part of the lake.

$\mathrm{p}=0.89$ ) being on average $5.9 \mathrm{~m}$ in the east and 6.0 in the south.

The width of the egg strands did not differ between individual A.S.S. (ANOVA; $\mathrm{F}_{2,77}=1.32, \mathrm{p}=0.27$ ) being, on average, $7.1 \mathrm{~cm}$ on green Norway spruce, $7.8 \mathrm{~cm}$ on dry Norway spruce and $8.0 \mathrm{~cm}$ on silver birch. Similarly, the width of egg strands did not differ between the eastern and southern localities (ANOVA; $F_{1,122}=1.93, \mathrm{p}=0.17$ ) being, on average, $7.0 \mathrm{~cm}$ on the east and $7.7 \mathrm{~cm}$ on the south. The width of the egg strands did, however, decrease significantly with increasing depth of deposition (regression analysis $_{\text {A.S.S. areas }} ; F_{1,78}=6.80, p=0.01$; regression analysis areas $_{\text {a }}$ outside the A.S.S.; $\left.F_{1,42}=8.16, p<0.01\right)$. Almost $84 \%$ of the egg strands came from females $\geq 200 \mathrm{~mm} L_{S}$.

The first perch larvae were present in the open water of Chabařovice Lake prior to mid-May 2010 since several egg strands deposited on A.S.S. in the 1-3 m depth layers had hatched, or at least partly hatched, on 13 May (Fig. 5). In contrast, an egg strand found on an A.S.S. at a depth of 9.8 $\mathrm{m}$ on 3 May had still not hatched on 3 June when the ex- 


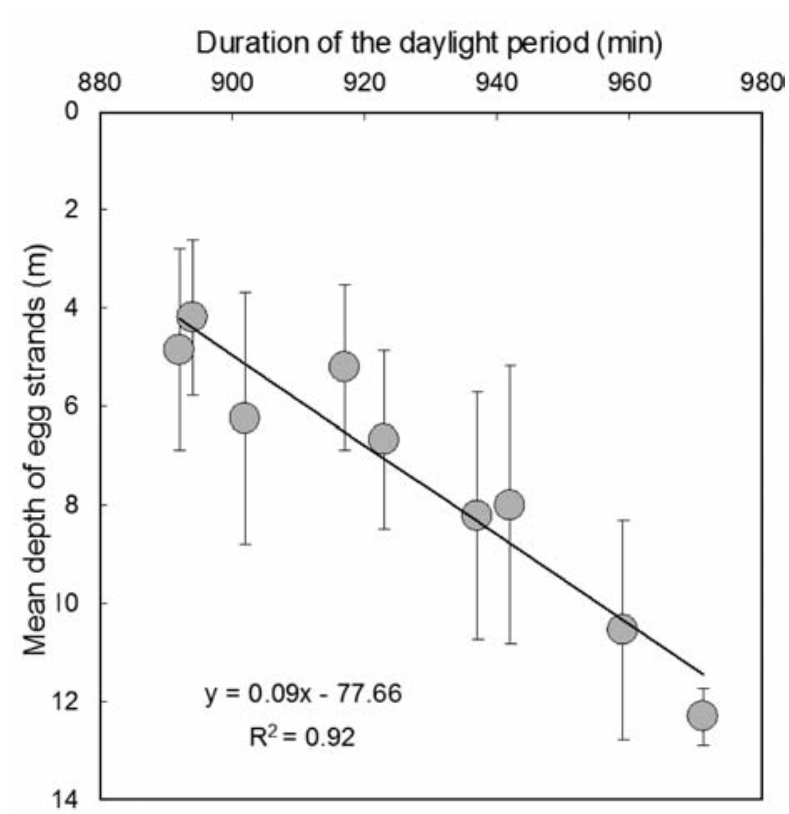

Fig. 4. The relationship between the duration of daylight period and depth (mean \pm S.D.) of newly spawned egg strands of perch in Chabařovice Lake in spring 2010 on nine dates in which the spawning was monitored (combined data from the A.S.S. areas and areas outside the A.S.S.).

periment terminated. According to the length of the perch spawning period in Chabařovice Lake (at least 5 weeks in 2010) and, according to the temperature in individual layers of the water column, it could be estimated that the latest larvae were in the open water not earlier than the beginning of July, i.e. more than one and a half months later (Fig. 5). In fact, in water $>12 \mathrm{~m}$ deep the hatching could have occurred at least up to mid-July since the water warming in these layers was very slow (an increase from 6.1 to $7.0^{\circ} \mathrm{C}$ was recorded during the period from 13 May to 12 July at $12 \mathrm{~m}$ depth).

A strong relationship was found between the CPUE of perch $\geq 200 \mathrm{~mm} L_{S}$ caught by gillnets in late summers of 2006-2009 and the CPUE of perch egg strands found by SCUBA divers during the following springs (regression analysis; $F_{1,2}=196.31, p<0.01$; Fig. 6). This relationship was based on 859 perch $\geq 200 \mathrm{~mm} L_{S}$ caught by gillnets, and 153 hours of day diving during which 1832 perch egg strands were found.

\section{DISCUSSION}

Although the spring sampling effort in Chabařovice Lake was very high each year [from 2007 onward; 38 \pm 4 hours (mean \pm S.D.) of day diving each year], the number of perch egg strands found decreased steadily from 896 in 2007 (Čech et al. 2009), to 581 in 2008 (Čech et al. 2010), 231 in 2009 (Čech et al. 2011) and, finally, to 124 in 2010 (this study). At the same time, the abundance of larger perch

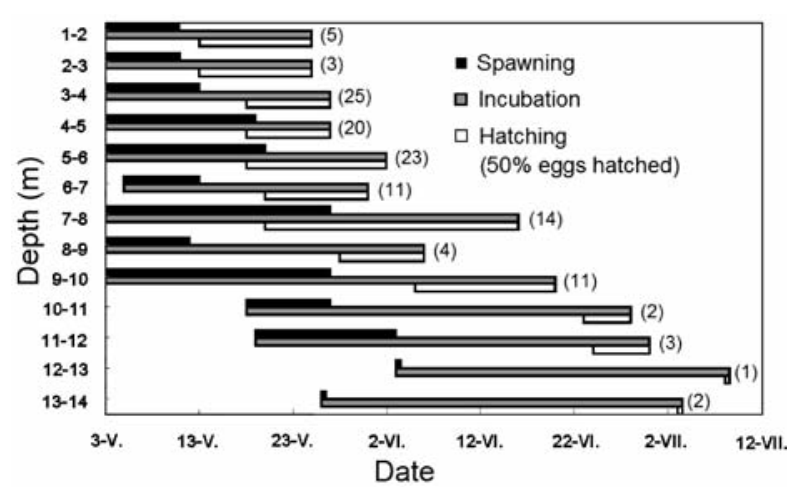

Fig. 5. A diagram showing the duration of spawning, incubation and hatching of perch egg strands in individual layers of Chabařovice Lake during spring 2010 (monitoring started on 3 May). The data in shallower layers were taken directly from the field, whereas in deeper layers $(>7 \mathrm{~m})$ the duration of the incubation period and hatching was calculated using the relationship between the time of incubation and actual temperature at the depth of the egg strands deposition provided in the work of Guma'a (1978) since many of these egg strands had not hatched at the time when the experiment terminated ( 3 June). Numbers in parentheses indicate numbers of spawned egg strands found in each depth layer (combined data from the A.S.S. areas and areas outside the A.S.S.).

$\left(\geq 200 \mathrm{~mm} L_{S}\right.$ ) in the lake also decreased steadily (Kubečka et al. 2007; Peterka et al. 2008, 2009, 2010). The relationship between the CPUE of perch $\geq 200 \mathrm{~mm} L_{S}$ (particularly females) caught by gillnets during the complex assessment of fish stock in Chabařovice Lake in late summer 20062009 and the CPUE of perch egg strands found during the SCUBA diving research next spring (2007-2010) indicated that decreasing numbers of larger perch females, without any doubt, resulted in a decreasing number of spawned egg strands.

The dramatic reduction of perch spawning stock in Chabařovice Lake seems to be partly a result of the progressive extinction of large fish from strong cohorts formed soon after the beginning of lake filling in year 2001 (cadavers of these fish have been found on the lake bottom since 2008; M. Čech, J. Peterka, unpubl. data) and partly a result of predation pressure from pike Esox lucius L. and wells catfish Silurus glanis L., which were stocked into the lake for biomanipulation purposes in the years 2005-2007 (Čech et al. 2011). The natural reproduction of the former has been highly successful and seems to be responsible for low perch recruitment (Kubečka et al. 2007; Peterka et al. 2008, 2009, 2010). For that reason younger and smaller perch females have not been able to compensate for the high mortality of older and larger females so that the whole population has declined. When considering the decreasing numbers of adult fish, poaching in this "no angling" water body can also not be excluded (F. Uhlír, pers. com.). 


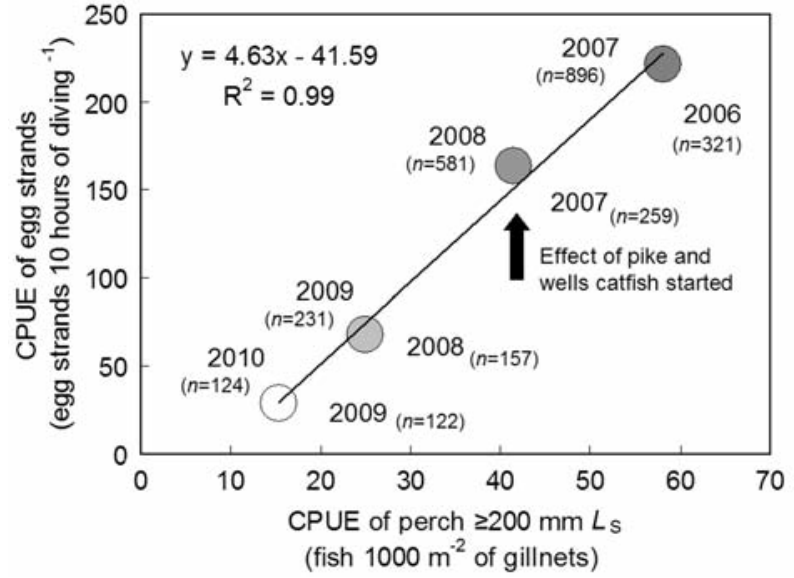

Fig. 6. The relationship between the CPUE of perch $\geq 200 \mathrm{~mm}$ $L_{S}$ caught by gillnets during the complex fish stock assessment of Chabařovice Lake in late summer (years 2006-2009) and the CPUE of perch egg strands found in the same lake during the SCUBA diving research in the following spring (years 20072010). Numbers indicate year of sampling, numbers in parentheses indicate numbers of egg strands found (left) or numbers of perch $\geq 200 \mathrm{~mm} L_{S}$ caught (right). The black arrow shows the period when wells catfish were stocked into the lake (autumn 2007) and when previously stocked individuals of pike (stocked in autumn 2005) grew to the size at which they were able to reduce perch spawning stock (cf. Peterka et al. 2008, 2009, 2010).

As has been documented for large pre-alpine lakes, such as Lake Zürich (Zeh et al. 1989) or Lake Geneva (Gillet et al. 1995; Gillet, and Dubois 1995; Gillet, and Dubois 2007), in Chabařovice Lake wind, and the resulting dangerous wave action, seems to be the main factor affecting the depth distribution of perch egg strands, especially in shallow depths and at the beginning of the spawning season. Due to the deforestation of the surrounding landscape, Chabařovice Lake is vulnerable to winds from all directions (Čech et al. 2009). Most probably, this is the reason why spawning perch completely avoid the $0-1 \mathrm{~m}$ depth layer around the whole lake shoreline (Čech et al. 2009, 2010, 2011, this study).

The prevailing winds come, however, from the southeast or from the north-west, i.e. following the longitudinal axis of the lake (Čech et al. 2011). On the east shore, in spring 2010, the wave action and strong current also resulted in the perch avoiding the 1-3 m depth layers. In contrast, along the relatively calm south shore, this phenomenon was not observed (this study). However, in total, $93.5 \%$ of egg strands were deposited at depths greater than $3 \mathrm{~m}$, which corresponds well to the previous results from Chabařovice Lake from 2007-2009 where 92\%, $88 \%$ and $91 \%$ of egg strands were deposited at depths greater than $3 \mathrm{~m}$ (Čech et al. 2009, 2010, 2011).

Prevailing winds and waves affected not only the depth distribution of egg strands but also site selection, since the windward east shore of Chabařovice Lake was generally less favoured by spawning perch while the calmer south shore was preferred. This conclusion corresponds well with the observation of Jones (1982) at Loch Leven, Scotland. In Chabařovice Lake, perch clearly avoided the shore with unstable conditions represented by waves, current, internal seiches and overall temperature instability of the water column. All these factors are hazardous for developing perch embryos (Clady, and Hutchinson 1975; Jones 1982; Newsome, and Aalto 1987; Aalto, and Newsome 1989).

In deeper layers $(>2 \mathrm{~m})$ of Chabařovice Lake, the depth distribution of egg strands seems to be controlled by temperature, particularly by the position of the 10$12^{\circ} \mathrm{C}$ water layers, mostly representing the thermocline. A similar correlation between the depth of perch spawning activity and the position of a $12^{\circ} \mathrm{C}$ water layer was described by Kubečka (1992) from Rímov Reservoir and by Gillet, and Dubois (1995) and Gillet et al. (2007) from Lake Geneva. A temperature of $12^{\circ} \mathrm{C}$ is optimal for the incubation of perch eggs (Swift 1965) with low-est embryo mortality (Guma'a 1978). Later in the spawning season, however, perch in Chabařovice Lake started to spawn in much colder water $\left(<10^{\circ} \mathrm{C}\right)$ and during the fourth and fifth weeks of spawning the deep-est egg strands, at between 12-14 m depth, were deposited at temperatures of only 5.3-6. $3^{\circ} \mathrm{C}$. Nikiforov (1937; in Guma'a 1978) found that the development of perch was slowed down at $6^{\circ} \mathrm{C}$ and stopped after some time, ending in the death of the embryos. In contrast, e.g. Filatov, and Duplakov (1926; in Thorpe 1977) found perch in the Aral Sea spawning under ice in temperatures $c a 4^{\circ} \mathrm{C}$. Unfortunately, the experimental study in Chabařovice Lake ended too early to be able to evaluate whether the eggs incubated at $<6^{\circ} \mathrm{C}$ finally developed to hatching.

During the years 2007 and 2008, perch were found to also spawn in much deeper layers of Chabařovice Lake than observed in 2010 and egg strands at between 15-20 $\mathrm{m}$ depths were not rare. However, they were spawned in temperatures between at least 7 and $8.5^{\circ} \mathrm{C}$ (Čech et al. 2009,2010 ), which are nearer to the observed range of temperature sufficient for perch spawning and egg development (for review see Thorpe 1977; Craig 1987). Unlike the years 2007 and 2008, in 2010 the mid-spring period was very cold and windy, with rainy and stormy weather prevailing. According to the Czech Hydrometeorological Institute (unpubl. data), May 2010 was significantly colder compared to the previous three years $\left(2.2-3.4^{\circ} \mathrm{C}\right.$ colder than May 2007-2009; ANOVA; $F_{3,120}=4.97$, $p<0.01)$. This resulted in a situation in which the continuous warming of the water column, which was regularly observed in previous years (Čech et al. 2009, 2010), was very poor in 2010. For that reason it seems likely that, at the end of the spawning season, perch do not react to the 
actual temperature of the water column but that they follow their inner clock, assuming that "normally" the shallower depth layers are too warm for successful embryo development. This hypothesis is well supported by the strong relationship between the depth at which egg strands were deposited and the duration of the daylight period (this study), which relationship could be thought to be trivial but represents the only reasonable explanation for such an unlikely spawning behaviour.

In this study, the perch spawning period lasted for 5 weeks (at least), which falls well within the range of published values for the length of the perch spawning period which range from 1-2 weeks (Treasurer 1983; Aalto, and Newsome 1989; Urho 1996) to more than 7-9 weeks (Craig 1974; Dalimier et al. 1982; Sandström et al. 1997) and corresponds to the 4-6 weeks given by Holčík (1969), Jones (1982), Gillet, and Dubois (1995) or Gillet et al. (2007). However, much more interesting than the length of the spawning period is the length of the hatching period, particularly the time difference between the presence of the first and last newly hatched perch larvae in the open water. The hatching period in Chabařovice Lake in 2010 lasted for almost two months. It could be argued that, with prolonged spawning and hatching periods and with spawning occurring in various depths and at various temperatures, perch have evolved a powerful mechanism to protect their population against the instability of the water environment. Annually, this spawning strategy ensures sufficient recruitment despite the vagaries of the weather and temporary bad biological conditions in the lake.

Several studies have demonstrated that perch could be lured to A.S.S. to either control their population ("biomanipulation purposes"; Jones 1982), to more easily study its spawning biology (Zeh et al. 1989; Gillet et al. 1995; Huff et al. 2004; Gillet, and Dubois 2007; Probst et al. 2009) or to support the reproduction success of this species (Nash et al. 1999; Pedicillo et al. 2008). In Chabařovice Lake, the A.S.S. was used for the latter two reasons, to homogenize the spawning sites and spawning depths on experimental areas and to improve perch spawning possibilities. Since two thirds of all the egg strands, which were found during the five weeks of monitoring perch spawning activity, were deposited on the A.S.S., it is likely that the last aim of this study was also at least partly successful. The presence of egg strands in areas outside the A.S.S. was extremely rare and most of them $(77.3 \%)$ were deposited on live Eurasian water milfoil and common stonewort. In the years 2007-2009, in contrast, only $6.0-28.9 \%$ of egg strands were found to be deposited on live submerged vegetation (Čech et al. 2009, 2010, 2011). Moreover, Čech et al. (2009, 2011) gave evidence that live submerged vegetation is not a very suitable spawning substrate for perch (most probably because it causes oxygen depletion at night in water surrounding the developing eggs) and is generally avoided. The alternative use of scarce live submerged vegetation as a spawning substrate supports previous statements of Čech et al. $(2009,2010,2011)$ that in Chabarovice Lake the most appropriate spawning substrate for perch, the beds of dead common reed and worm weed, have shown signs of progressive degradation and have gradually disappeared from the lake. The rest of these substrates (together with dislodged branches, dead trees and bushes), due to the continuous filling of the lake, are now in water too deep for most of the perch spawning activity, to be used for deposition of egg strands. Such knowledge legitimizes the installation of A.S.S. in this opencast mine lake and supports the idea of using A.S.S. in an effort to enhance spawning possibilities for the local perch population.

Until now, the above mentioned problem with natural spawning substrates, together with high predation pressure, imposed by both stocked and now well-reproducing predators, and by poachers, increases reproduction and recruitment difficulties of perch, the key species, in Chabařovice Lake.

\section{CONCLUSIONS}

The present study has shown that the depths and site preferences used by spawning perch are not dependent on the presence of suitable spawning substrates since the results were similar in both the A.S.S. areas and in areas outside the A.S.S. The avoidance by spawning perch of shallow depth layers, proven in this study by using experimental areas with A.S.S., supports the previous observations of Čech et al. (2009, 2010, 2011). Factors influencing the depth distribution of egg strands were identified as waves, temperature and duration of the daylight period. Factors influencing their selection of spawning sites were identified as a wind inducing current, internal seiches and temperature instability of the water column.

The possibility of a lack of suitable natural spawning substrates reported for Chabařovice Lake in previous years (Čech et al. 2010, 2011) was revealed to be critical in 2010 (M. Čech, L. Vejř́k, J. Peterka, M. Říha, unpubl. data) and thus justified the use of A.S.S. to increase the success of perch reproduction in the lake. From the results presented it is evident that windward shores are not very suitable for A.S.S. and, similarly, the installation of A.S.S. into 1 and $15 \mathrm{~m}$ depths is also useless for supporting perch reproduction. To increase the spawning possibilities for perch in Chabařovice Lake in the near future, it is suggested that four A.S.S. areas should be created by the calm south shore and another four A.S.S. areas by the calm north shore (installation depths 5-11 m). This intervention should maintain a sustainable perch stock in the lake even with a complete lack of suitable natural spawning substrates. However, the negative effect of pike and wells cat- 
fish still has to be taken into consideration.

Present knowledge of how the perch population in Chabarrovice Lake reacts to the lack of spawning substrates, and to the predation pressure, is of crucial importance for the management of other large water bodies forming in the region of North-West Bohemia (opencast mine lakes; total area $>2100$ ha) where a key role of perch is also expected (Čech et al. 2011).

\section{ACKNOWLEDGMENTS}

The authors thank Z. Prachar for help with the exhausting installation of the A.S.S. and M. Morris for careful reading and correcting the English. The study was supported by the Grant Agency of the Czech Republic (project No. 206/09/P266) and the Palivový kombinát Ústí, státní podnik.

\section{REFERENCES}

Alto SK, and Newsome GEB. 1989. Evidence of demic structure for a population of yellow perch (Perca flavescens). Can. J. Fish. Aquat. Sci. 46: 184-190.

CEN. 2005. European Standard EN 14757 2005. Water quality - Sampling of fish with multimesh gillnets, CEN TC 230, March 2005.

Craig JF. 1974. Population dynamics of perch, Perca fluviatilis L. in Slapton Ley, Devon. Freshwater Biol., 4: 417-431.

Craig JF. 1987. The biology of perch and related fish. Croom Helm Ltd, Kent: 333 pp.

Clady MD, and Hutchinson B. 1975. Effect of high winds on eggs of yellow perch, Perca flavescens, in Oneida Lake, New York. T. Am. Fish. Soc. 104: 524-525.

Čech M, Peterka J, Říha M, Jůza T, and Kubečka J. 2009. Distribution of egg strands of perch (Perca fluviatilis L.) with respect to depth and spawning substrate. Hydrobiologia 630: 105-114.

Čech M, Peterka J, Říha M, Draštík V, Kratochvíl M, and Kubečka J. 2010. Deep spawning of perch (Perca fluviatilis L.) in the newly created Chabarovice Lake, Czech Republic. Hydrobiologia 649: 375-378.

Čech M, Peterka J, Říha M, Muška M, Hejzlar J, and Kubečka J. 2011. Location and timing of the deposition of egg strands by perch (Perca fluviatilis L.): the roles of lake hydrology, spawning substrate and female size. Knowl. Manag. Aquat. Ec. 403/08: 1-12.

Dalimier N, Philippart JC, and Voss J. 1982. An eco-ethological study of the reproduction of Perca fluviatilis L. as observed by diving in an inundated quarry pit. Cahiers d'Ethologie appliquée 2/1: 37-52 (in French with summary in English).

Dubois JP, Gillet C, Bonnet S, and Chevalier-Weber Y. 1996. Correlation between the size of mature female perch (Perca fluviatilis L.) and the width of their egg strands in Lake Geneva. Ann. Zool. Fenn. 33: 417-420.

Gillet C, and Dubois JP. 1995. A survey of the spawning of perch (Perca fluviatilis), pike (Esox lucius), and roach (Rutilus rutilus), using artificial spawning substrate in lakes. Hydrobiologia 300-301: 409-414.

Gillet C, and Dubois JP. 2007. Effect of water temperature and size of females on the timing of spawning of perch Perca fluviatilis L. in Lake Geneva from 1984 to 2003. J. Fish Biol. 70: 1001-1014.

Gillet C, Dubois JP, and Bonnet S. 1995. Influence of temperature and size of females on the timing of spawning of perch, Perca fluviatilis, in Lake Geneva from 1984 to 1993. Environ. Biol. Fish. 42: 355-363.

Guma'a S.A. 1978. The effects of temperature on the development and mortality of eggs of perch, Perca fluviatilis. Freshwater Biol. 8: 221-227.

Holčík J. 1969. The natural history of perch, Perca fluviatilis, Linneaus 1758, in the Klíčava reservoir. Práce Laboratoria Rybárstva 2: 269-305.

Huff DD, Grad G, and Williamson CE. 2004. Environmental constraints on spawning depth of yellow perch: the roles of low temperature and high solar ultraviolet radiation. Trans. Am. Fish. Soc. 133: 718-726.

Jones DH. 1982. The spawning of perch (Perca fluviatilis, L.) in Loch Leven, Kinross, Scotland. Fish. Manag. 13: 139151 .

Kubečka J. 1992. Fluctuations in fyke-net catches during the spawning period of the Eurasian perch (Perca fluviatilis) in the Římov Reservoir, Czechoslovakia. Fish. Res. 15: 157167.

Kubečka J, Peterka J, Draštík V, Jůza T, Prchalová M, and Ř́iha M. 2007. Complex fish stock assessment of Chabařovice Lake in year 2006. Report of the Biology Centre, Academy of Sciences of the Czech Republic, Institute of Hydrobiology: 59 pp (in Czech).

Nash KT, Hendry K, and Cragg-Hine D. 1999. The use of brushwood bundles as fish spawning media. Fisheries Manag. Ecol. 6: 349-355.

Newsome GE, and Aalto SK. 1987. An egg-mass census method for tracking fluctuations in yellow perch (Perca flavescens) populations. Can. J. Fish. Aquat. Sci. 44/6: 1221-1232.

Pedicillo G, Merulli F, Carosi A, Viali P, and Lorenzoni M. 2008. The use of artificial spawning substrates as media to support the reproduction of Eurasian perch in Lake Piediluco. Hydrobiologia 609: 219-223.

Peterka J, Kubečka J, Čech M, Draštík V, Frouzová J, Jůza T, and Prchalová M. 2008. Complex fish stock assessment of Chabařovice Lake in year 2007. Report of the Biology Centre, Academy of Sciences of the Czech Republic, Institute of Hydrobiology: 82 pp (in Czech).

Peterka J, Kubečka J, Draštík V, Jůza T, Frouzová J, Čech M, and Prchalová M. 2009. Complex fish stock assessment of Chabařovice Lake in year 2008. Report of the Biology Centre, Academy of Sciences of the Czech Republic, Institute of Hydrobiology: 47 pp (in Czech).

Peterka J, Kubečka J, Draštík V, Čech M, Jůza T, Frouzová J, and Prchalová M. 2010. Complex fish stock assessment of Chabařovice Lake in year 2009. Report of the Biology Centre, Academy of Sciences of the Czech Republic, Institute of Hydrobiology: 44 pp (in Czech).

Probst WN, Stoll S, Hofmann H, Fischer P, and Eckmann R. 2009. Spawning site selection by Eurasian perch (Perca fluviatilis L.) in relation to temperature and wave exposure. Ecol. Freshwater Fish. 18: 1-7.

Sandström O, Abrahamsson I, Andersson J, and Vetemaa M. 1997. Temperature effects on spawning and egg develop- 
ment in Eurasian perch. J. Fish Biol. 51: 1015-1024.

Swift DR. 1965. Effect of temperature on mortality and rate of development of the eggs of the pike (Esox lucius L.) and the perch (Perca fluviatilis L.). Nature 206: 528.

Thorpe J. 1977. Synopsis of biological data on the perch Perca fluviatilis Linnaeus, 1758 and Perca flavescens Mitchill, 1814. FAO Fisheries Synopsis No. 113, Rome: 138 pp.

Treasurer JW. 1983. Estimates of egg and viable embryo production in a lacustrine perch, Perca fluviatilis. Environ. Biol.
Fish. 8/1: 3-16.

Urho, L. 1996. Habitat shifts of perch larvae as survival strategy. Ann. Zool. Fenn. 33: 329-340.

Williamson CE, Metzgar SL, Lovera PA, and Moeller RE. 1997. Solar ultraviolet radiation and the spawning habitat of yellow perch, Perca flavescens. Ecol. Appl. 7: 1017-1023.

Zeh M, Ritter E, and Ribi G. 1989. Spawning and egg development of Perca fluviatilis in Lake Zürich. Aquat. Sci. 51/2: 100-107. 